\section{JURNAL EKONOMI EFEKTIF}

ISSN : $2622-8882$, E-ISSN : 2622-9935

Jurnal Ekonomi Efektif, Vol. 3, No. 2, Januari 2021 @Prodi Manajemen Fakultas Ekonomi Universitas Pamulang

\title{
PENGARUH STRATEGI PROMOSI DAN HARGA TERHADAP KEPUTUSAN PEMBELIAN PRODUK BAHAN BAKU BIJI PLASTIK PADA PT. KURNIA MAKMUR JAYA LESTARI DI GADING SERPONG
}

\author{
Suwanto \\ Universitas Pamulang, Tangerang Selatan, Banten, Indonesia \\ dosen01813@unpam.ac.id
}

Manuskrip: Sept-2020; Ditinjau: Okt-2020; Diterima: Okt-2020; Online: Jan-2021; Diterbitkan: Jan-2021

\begin{abstract}
ABSTRAK
Penelitian ini bertujuan untuk mengetahui pengaruh strategi promosi dan penetapan harga baik secara parsial maupun secara simultan terhadap keputusan pembelian. Populasi adalah konsumen yang membeli produk Pada PT. Kurnia Makmur Jaya Lestari dengan jumlah semple yang digunakan 100 konsumen. Metode analisis data yang digunakan adalah analisis regresi linier berganda, koefisien kolerasi product moment, koefisien determinasi dan uji signifikasi. Hasil analisis terdapat pengaruh baik secara parsial maupun simultan terhadap keputusan pembelian dimana diperoleh hasil kofisien regresi linier berganda sebesar $\mathrm{Y}=5,251$ $+0,517 \mathrm{X} 1+0,057 \mathrm{X} 2+$ e., koefisien korelasi product moment diperoleh nilai r sebesar 0,852., koefisien determinasi diperoleh nilai KD sebesar 72,6\%., hasil uji $\mathrm{F}$ dapat diperoleh nilai nilai F hitung > f tabel yaitu 128,291 > 4,00
\end{abstract}

Kata Kunci: Strategi Promosi, Penetapan Harga, Volume Penjualan.

\section{ABSTRACT}

This study aims to determine the effect of promotional strategies and pricing both partially and simultaneously on purchasing decisions. The population are consumers who buy products at PT. Kurnia Makmur Jaya Lestari with the number of samples used by 100 consumers. The data analysis method used is multiple linear regression analysis, product moment correlation coefficient, coefficient of determination and significance test. The results of the analysis there is an effect both partially and simultaneously on purchasing decisions where the results of the multiple linear regression coefficient are $Y=5.251+0.517 X 1+0.057$ $X 2+e$, the product moment correlation coefficient obtained $r$ value of 0.852 . The coefficient of determination obtained KD value of $72.6 \%$.. the $F$ test, it can be obtained that the value of $F$ count $>$ f table is $128.291>4.00$

Keywords: Promotion Strategy, Pricing, Sales Volume. 


\section{PENDAHULUAN}

\section{A. Latar Belakang Masalah}

Di era globalisasi yang berkembang pesat ini dimana semua pihak sudah dapat secara bebas memasuki setiap pasar yang dikehendaki baik itu di dalam negeri maupun di luar negeri tanpa ada batasannya lagi. Perusahaan dapat menjual produk dengan harga yang menguntungkan pada tingkat kualitas yang diharapkan untuk meningkatkan penjualan, perusahaan bersaing semakin ketat untuk meraih peluang yang ada untuk memenuhi keinginan dan kebutuhan konsumen. Manajemen adalah suatu proses perencaan, pengorganisasian, leadership, serta pengendalian upaya dari anggota organisasi tersebut serta penggunaan Sumber daya yang tersedia di organisasi tersebut guna mencapai suatu tujuan yang telah ditetapkan organisasi sebelumnya

George R. Terry dalam buku Principles of Management (Sukarna, 2011:3), juga menyatakan bahwa management is the accomplishing of a predetemined obejectives through the efforts of otherpeople atau manajemen adalah pencapaian tujuan-tujuan yang telah ditetapkan melalui atau bersama-sama usaha orang lain dan membagi empat fungsi dasar manajemen, yaitu Planning (Perencanaan), Organizing (Pengorganisasian), Actuating (Pelaksanaan) dan Controlling (Pengawasan). Keempat fungsi manajemen ini disingkat dengan POAC. Manajemen Pemasaran adalah merupakan alat analisis, perencanaan, penerapan, dan pengendalian program yang dirancang untuk menciptakan, membangun, dan mempertahankan pertukaran yang menguntungkan dengan target pasar sasaran dengan maksud untuk mencapai tujuan utama perusahaan yaitu memperoleh laba. Pengertian konsep pemasaran adalah suatu konsep dan cara dasar yang di terapkan dalam melakukan strategi manajemen pemasaran produk atau jasa pada sebuah organisasi ataupun perusahaan. Ada juga yang mendefinisikan pengertian konsep pemasaran adalah : Sebuah falsafah bisnis yang menyatakan bahwa pemuasan kebutuhan konsumen merupakan syarat ekonomi dan sosial bagi kelangsungan hidup perusahaan. Sebagaimana telah di sebutkan pada tulisan saya sebelumnya bahwa konsep marketing mencakup 6 hal : konsep produksi, konsep produk, konsep penjualan, konsep pemasaran, konsep pemasaran sosial, dan konsep pemasaran global. Elemen Penting dalam Konsep Pemasaran:

a. Market oriented berorientasi pada keinginan Konsumen

b. Penyusunan kegiatan pemasaran secara terpadu

c. Pencapaian tingkat kepuasan Konsumen

Pemasaran adalah salah satu kegiatan pokok yang perlu dilakukan oleh perusahaan baik itu perusahaan barang atau jasa dalam upaya untuk mempertahankan kelangsungan hidup usahanya. Hal tersebut disebabkan karena pemasaran merupakan salah satu kegiatan perusahaan, di mana secara langsung berhubungan dengan konsumen. Maka kegiatan pemasaran dapat diartikan sebagai kegiatan manusia yang berlangsung dalam kaitannya dengan pasar. Promosi adalah suatu kegiatan bidang marketing yang merupakan komunikasi yang dilaksanakan perusahaan kepada pembeli atau konsumen yang memuat pemberitaan, membujuk, dan mempengaruhi segala sesuatu mengenai barang maupun jasa yang dihasilkan untuk konsumen, segala kegiatan itu bertujuan untuk meningkatkan volume penjualan dengan menarik minat konsumen dalam mengambil keputusan membeli di perusahaan tersebut. strategi promosi merupakan kegiatan yang direncanakan dengan maksud membujuk, merangsang konsumen agar mau membeli produk perusahaan sehingga tujuan untuk meningkatkan penjualan diharapkan dapat tercapai.

Menjalankan sebuah bisnis jual-beli tidak akan terlepas dari permasalahan harga. Harga memegang peranan penting dalam terjadinya kesepakatan jual-beli dari produsen 
ke tangan konsumen. Melalui penetapan harga, akan terlihat posisi kelayakan produk dari nilai ekonomisnya. Karena permasalahan ini, perusahaan biasanyan mengadakan penetapan harga yang disepakati sebelum barang beredar di pasaran. Harga memainkan peran strategik dalam pemasaran.Bila harga terlalu mahal, maka produk bersangkutan bakal tidak terjangkau oleh pasar sasaran tertentu atau bahkan customer value menjadi rendah.Sebaliknya, jika harga terlampau murah, perusahaan sulit mendapatkan laba atau sebagian konsumen mempersepsikan kualitasnya buruk. Elemen-elemen bauran pemasar lainnya, bila dipergunakan secara tepat, maka harga dapat menjadi senjata strategik untuk bersaing secara efektif. Harga dapat disesuaikan atau diubah secara dramatis, tergantung apa yang ingin dicapai. Kendati demikian, penetapan harga secara tepat merupakan faktor penting dalam menentukan kesuksesan perusahaan dalam jangka pendek dan jangka panjang (Tjiptono, 2015:289)..

\section{B. Rumusan Masalah}

Berdasar kan latar belakang dan judul penelitian ini, maka peneliti merumuskan masalah sebagai berikut :

1. Bagaimana Strategi promosi berpengaruh terhadap Keputusan pembelian bahan baku biji plastik pada PT Kurnia Makmur Jaya Lestari ?

2. Bagaimana harga berpengaruh terhadap Keputusan pembelian bahan baku biji plastik pada PT Kurnia Makmur Jaya Lestari ?

3. Seberapa besar Strategi Promosi dan Harga berpengaruh terhadap Keputusan pembelian bahan baku biji plastik PT Kurnia Makmur Jaya Lestari ?

\section{Tujuan Penelitian}

1. Untuk mengetahui pengaruh strategi promosi terhadap Keputusan pembelian bahan baku biji plastik pada PT Kurnia Makmur Jaya Lestari

2. Untuk mengetahui pengaruh harga terhadap Keputusan pembelian bahan baku biji plastik pada PT Kurnia Makmur Jaya Lestari.

3. Untuk mengetahui pengaruh Strategi promosi dan harga terhadap Keputusan pembelian bahan baku biji plastik pada PT Kurnia Makmur Jaya Lestari

\section{METODE PENELITIAN}

\section{Populasi}

Populasi dalam penelitian ini berjumlah 100 responden yaitu karyawan PT. Kurnia Makmur Jaya Lestari

2. Sampel

Teknik pengambilan sampling dalam penelitian ini adalah insedental sampling, Dengan demikian sampel dalam penelitian ini berjumlah 100 responden.

\section{Jenis Penelitian}

Jenis penelitian yang dipakai adalah asosiatif, dimana tujuannya adalah untuk mengetahui mencari keterhubungan antara variabel independen terhadap variabel dependennya

\section{Metode Analisis Data}

Dalam menganalisis data digunakan uji validitas, uji reliabilitas, analisis regresi linier sederhana, koefisien korelasi, koefisien determinasi dan uji hipotesis. 


\section{HASIL PENELITIAN DAN PEMBAHASAN}

\section{Hasil Uji Regresi Linear Berganda}

Berdasarkan uji dengan program SPSS diperoleh hasil regresi berganda seperti terangkum pada tabel berikut :

Tabel 1

Hasil Uji Regresi Linear Berganda

Coefficients $^{\text {a }}$

\begin{tabular}{|c|c|c|c|c|c|c|c|c|}
\hline \multirow{2}{*}{\multicolumn{2}{|c|}{ Model }} & \multicolumn{2}{|c|}{\begin{tabular}{|l|} 
Unstandardized \\
Coefficients \\
\end{tabular}} & \multirow{2}{*}{$\begin{array}{c}\begin{array}{c}\text { Standardized } \\
\text { Coefficients }\end{array} \\
\text { Beta }\end{array}$} & \multirow[b]{2}{*}{$\mathrm{T}$} & \multirow[b]{2}{*}{ Sig. } & \multicolumn{2}{|c|}{ Collinearity Statistics } \\
\hline & & B & Error & & & & Tolerance & VIF \\
\hline \multirow[t]{3}{*}{1} & (Constant) & 5,251 & 1,894 & & 2,772 & ,007 & & \\
\hline & PROMOS & ,517 & ,035 & ,823 & 14,731 &, 000 & ,907 & 1,103 \\
\hline & HARGA & ,057 & ,038 & ,084 & 1,498 & ,137 & ,907 & 1,103 \\
\hline
\end{tabular}

a. Dependent Variable: Keputusan Pembelian

Sumber: Output SPSS yang diolah 2019

\section{Uji Koefisien Determinasi}

Menurut Sugiyono (2012:50) Koefisien Determinasi (R2) bertujuan untuk mengetahui seberapa besar kemampuan variabel independent menjelaskan variabel dependent. Berdasarkan uji dengan program SPSS 20 diperoleh hasil uji koefisien determinasi seperti pada tabel berikut :

\section{Tabel 2}

Hasil Uji Koefisien Determinasi Model Summary ${ }^{b}$

\begin{tabular}{|c|c|c|c|c|}
\hline Model & $\mathrm{R}$ & $\mathrm{R}$ Square & Adjusted R Square & $\begin{array}{l}\text { Std. Error of the } \\
\text { Estimate }\end{array}$ \\
\hline 1 & $.852^{\mathrm{a}}$ &, 726 &, 720 & 2,553 \\
\hline
\end{tabular}

a. Predictors: (Constant), Harga, Promosi

b. Dependent Variable: Keputusan Pembelian

\section{Pengujian Hipotesis}

Uji statistik F pada dasarnya menunjukan apakah semua variabel independen yang dimasukan dalam model mempunyai pengaruh secara bersama-sama terhadap variabel dependenya. Hasil perhitungan Uji F dapat dilihat pada tabel:

Tabel 3

Hasil Uji F (simultan)

ANOVA $^{\mathrm{a}}$

\begin{tabular}{|cl|c|c|c|c|}
\hline Model & & Sum of Squares & Df & Mean Square & F \\
\hline 1 & Regression & 1672,593 & 2 & 836,296 & 128,291 \\
& Residual & 632,317 & 97 & 6,519 & \\
& Total & 2304,910 & 99 & & \\
& & & & \\
\end{tabular}

a. Dependent Variable: Keputusan Pembelian

b. Predictors: (Constant), Harga, Promosi

Sumber : Output spss yang di olah (2019)

Dari hasi uji $\mathrm{F}$ dapat diperoleh nilai $\mathrm{F}_{\text {hitung }}>\mathrm{f}_{\text {tabel }}$ yaitu $128,291>\mathbf{4 , 0 0}$ dan nilai sig $<0,01$ atau $0,000<0,01 "$ terdapat pengaruh Strategi promosi dan harga secara simultan Terhadap keputusan pembelian bahan baku biji plastik pada PT Kurnia Makmur Jaya Lestari". 


\section{PENUTUP}

\section{Kesimpulan}

a. Berdasarkan data dari tabel kuesioner variabel penetapan harga $\left(\mathrm{x}_{1}\right)$ maka terlihat nilai rata-rata yaitu 38,93 berada di kategori skala (3,41 - 4,20: Tinggi) dimana tanggapan responden terhadap variabel strategi promosi $\left(\mathrm{x}_{1}\right)$ memiliki kategori skala tinggi atau baik, dilihat dari skor tertinggi 4,04 yaitu pada petanyaan "Saya sering kali melihat promosi di PT. Kurnia Makmur Jaya Lestari " dan " Alasan saya membeli di PT Kurnia Makmur Jaya Lestari karena kualitas karyawannya" Sehingga banyak responden yang melihat berbagai promosi yang dijual oleh PT Kurnia Makmur Jaya Lestari, serta kualitas pelayanan dari karyawan PT Kurnia Makmur Jaya Lestari sangat baik. Dengan demikian hal ini dapat menjadi motivasi untuk selalu meningkatkan kinerja dalam segala aspek demi untuk meningkatkan keputusan pembelian.

b. Berdasarkan data dari tabel kuesioner variabel harga (x2) maka terlihat nilai rata-rata yaitu 46,83 berada di kategori skala (4,20 - 5,00 : Sangat Tinggi) dimana tanggapan responden terhadap variabel harga (x2) memiliki kategori skala tinggi atau baik, dilihat dari skor tertinggi 4,15 yaitu pada pertanyaan "Perusahaan yang menjadi konseumen PT. Kurnia Makmur Jaya Lestari sudah merasa puas dengan produk dan harga yang ditetapkan sehingga mereka memperoleh keuntungan yang besar". Dengan demikian banyak responden yang memilih PT. Kurnia Makmur Jaya Lestari sebagai perusahaan yang memiliki produk berkualitas dengan menentukan harga terbaik, sehingga perusahaan konsumen dapat memperoleh keuntungan yang besar dengan menjadi pelanggan dari PT Kurnia Makmur Jaya Lestari. Dengan demikian hal ini dapat menjadi motivasi untuk selalu meningkatkan kinerja dalam segala aspek demi untuk meningkatkan keputusan pembelian.

c. Berdasarkan data dari tabel kuesioner variabel keputusan pembelian (Y) maka terlihat nilai rata-rata yaitu 28,03 berada di kategori skala $(3,41-4,20$ : Baik) dimana tanggapan responden terhadap variabel keputusan pembelian (y) memiliki kategori skala tinggi atau baik, dilihat dari skor tertinggi 4,09 yaitu pada pernyataan "PT Kurnia Makmur jaya Lestari menjadi alternatif pilihan konsumen dalam membeli produk biji plastik" hal ini membuktikan bahwa produk yang diberikan oleh PT Kurnia Makmur Jaya Lestari sudah bagus, sehingga banyak konsumen yang menjadikan alternatif untuk digunakan.

\section{Saran}

a. Berdasarkan data dari tabel kuesioner variabel strategi promosi $\left(\mathrm{x}_{1}\right)$ maka pihak perusahaan harus lebih meningkatkan strategi promosi dari segi "Sering kali program promosi yang berlaku dipromosikan melalui iklan (sosial media, media cetak) menarik saya untuk membelinya" dimana diperoleh skor terendah 3,77. Maka dari itu perusahaan harus meningkatkan kembali strategi promosi di berbagai media cetak dan media sosia yang dimana hal ini memperoleh skor terendah dari semua pertanyaan kuesioner di variabel strategi promosi, dengan demikian hal ini harus menjadi perhatian lebih untuk diperbaiki dan ditingkatkan demi bisa meningkatkan keputusan pembelian pada PT Kurnia Makmur Jaya Lestari.

b. Berdasarkan data dari tabel kuesioner variabel harga (x2 ) pihak perusahaan harus lebih memperhatikan harga jual produk dari segi "Dalam memberikan harga, PT. Kurnia Makmur Jaya Lestari tidak mengenakan biaya tambahan." dimana diperoleh skor terendah 3,65. Maka dari itu perusahaan konsumen harus memperhatikan kembali harga yang diberikan oleh PT Kurnia Makmur Jaya Lestari ada atau tidak 
nya biaya tambahan seperti pinalti ongkos kirim atau sejenisnya yang membuat perusahaan konsumen harus mengeluarkan biaya tambahan. Dengan demikian hal ini harus menjadi perhatian lebih untuk diperbaiki dan ditingkatkan demi bisa meningkatkan keputusan pembelian pada PT Kurnia Makmur Jaya Lestari.

c. Berdasarkan data dari tabel kuesioner variabel keputusan pembelian (y) perusahaan harus lebih meningkatkan keputusan pembelian dari segi "Produk yang ada di PT Kurnia Makmur Jaya Lestari memiliki banyak pilihan ketika dibeli konsumen." dimana diperoleh skor terendah 3,88. Berdasarkan skor tersebut produk yang di miliki PT Kurnia Makmur Jaya Lestari kurang bervariasi, sehingga konsumen kurang memiliki banyak refrensi untuk membeli produk. Hal ini harus menjadi perhatian khusus agar bisa meningkatkan keputusan pembelian konsumen PT Kurnia Makmur Jaya Lestari.

\section{DAFTAR PUSTAKA}

Abdullah, M (2014) Manajemen dan Evaluasi Kinerja Karyawan, Yogyakarta: Penerbit Aswaja Pressindo.

Dessler, G. (2006.) Manajemen Sumber Daya Manusia (Jilid II). Jakarta: Indeks..

Effendy, A. A., Sunarsi, D., Kristianti, L. S., Irawati, L., \& Wahyitno, W. (2020). Effect Of Giving Reward and Motivation to Employee Productivity In PT. Sinar Kencana Jaya In Surabaya. HUMANIS (Humanities, Management and Science Proceedings), 1(1). Erlangga, H. (2020). The Challenges of Organizational Communication in the Digital Era. Solid State Technology, 63(4), 1240-1246.

Gandung, M., \& Suwanto, S. (2020). Analisis Pengaruh Kompensasi Dan Gaya Kepemimpinan Terhadap Kinerja Karyawan Pada PT. Surya Rasa Loka Jaya Di Jakarta Barat. JENIUS (Jurnal Ilmiah Manajemen Sumber Daya Manusia), 3(3), 236245.

George Terry R \& Rue, Leslie W. Rue (2016) Dasar-Dasar Manajemen, Jakarta Bumi Aksara.

Gerry Dessler (2016) Human Resources Management, Prenticehall, London: International Inc.

Hasibuan, Malayu S.P. (2016). Manajemen Sumber Daya Manusia. Edisi Revisi. Jakarta: PT Bumi Aksara.

Imam Ghozali (2017). “Aplikasi Analisis Multivariate Dengan Program SPSS”. Edisi Kelima. Semarang: Badan Penerbit Undip.

Istijanto (2014) “Riset Sumber Daya Manusia”. Jakarta: PT. Gramedia Pustaka

Jasmani, J., \& Paeno, P. (2019). The Effect of Leadership and Competence on Lecturer Performance and Its Implications on Student Learning Motivation at Pamulang University. International Journal of Advances in Social and Economics, 1(4).

Khoiri, A., Nasihah, U., \& Kahar, M. S. (2017). Analisis prestasi belajar fisika berpendekatan SETS di tinjau dari motivasi berprestasi. Jurnal Riset dan Kajian Pendidikan Fisika, 4(2), 83-89.

Luthans Fred (2014) Organizational Behavior, Ney York: McGraw-Hill, New York.

Mangkunegara, Prabu Anwar. (2016). Evaluasi Kinerja SDM. Cetakan ke tujuh, PT Refika Aditama: Bandung.

Robbins, P.S, \& Judge, A.T. (2003). Organizational Behavior. Jakarta: Salemba Empat.

Sarwani, S., Akbar, I. R., Handoko, A. L., \& Ilham, D. (2020). Pengaruh Pelatihan dan Motivasi terhadap Produktivitas Kerja Karyawan pada PT. Lion Mentari Airlines Bandara Internasional Soekarno Hatta Cengkareng. Jurnal Ilmu Komputer dan Bisnis, 11(2a), 91-100 
Sarwani, S., Akbar, I. R., Handoko, A. L., \& Ilham, D. (2020). Pengaruh Pelatihan dan Motivasi terhadap Produktivitas Kerja Karyawan pada PT. Lion Mentari Airlines Bandara Internasional Soekarno Hatta Cengkareng. Jurnal Ilmu Komputer dan Bisnis, 11(2a), 91-100.

Sobarna, A., Rizal, R. M., Hambali, S., \& Sunarsi, D. (2020). Influence Make a Match Model toward Communication skills in Physical and Health Pedagogical Concept. Solid State Technology, 63(6), 1355-1363.

Sugiyono (2017), "Metode Penelitian Administrasi : dilengkapi dengan Metode $R \&$ D”. Bandung: Alfabeta.

Sunarsi, D. (2018). Buku Ajar: Seminar Perencanaan Sumber Daya Manusia. Tangerang Selatan: Asmoro Mediatama

Suwanto, S. (2019). Pengaruh Disiplin Kerja Dan Motivasi Kerja Terhadap Kinerja Karyawan Pada Rumah Sakit Umum Tangerang Selatan. JENIUS (Jurnal Ilmiah Manajemen Sumber Daya Manusia), 3(1), 16-23.

Suwanto, S. (2019). Pengaruh Disiplin Kerja Dan Motivasi Kerja Terhadap Kinerja Karyawan Pada Rumah Sakit Umum Tangerang Selatan. JENIUS (Jurnal Ilmiah Manajemen Sumber Daya Manusia), 3(1), 16-23.

Suwanto, S. (2019). Pengaruh Gaya Kepemimpinan Dan Lingkungan Kerja Terhadap Kinerja Karyawan Unit Telesales Pada PT BFI Finance Indonesia TBK. Jurnal Ekonomi Efektif, 1(2).

Suwanto, S., \& Eka, P. D. (2020). Analysis Of Leadership Style Influence, Job Motivation, And Compensation Towards Teacher Satisfaction On The Foundation Of Al-Hasra Bojongsari. Depok City. International Journal of Advances in Social and Economics, 2(3).

Suwanto, S., Eka, P. D., Agusentoso, R., Juanda, A., \& Kurniawan, P. (2020). Menggali Potensi, Memotivasi Dan Mengarahkan Generasi Muda Menyongsong Dunia Kerja Pada PKBM Cipta Tunas Karya Cipondoh Kota Tangerang. Jurnal Pengabdian Dharma Laksana, 2(2), 132-136.

Syobar, K., Hardiyan, A., Romlah, O. Y., Yusup, M., \& Sunarsi, D. (2020). The Effect of Service Quality and Price on Purchase Decisions in Woodpecker Coffee in South Jakarta. Solid State Technology, 63(6), 1491-1504.

Veithzal Rivai (2015) Manajemen Sumber Daya Manusia Untuk Perusahaan, Jakarta: Raja Grafindo Persada.

Wibowo (2015) Manajemen Kinerja, Jakarta: PT. Raja Grafindo Persada

Yuangga, K. D., \& Sunarsi, D. (2018). The Influence of Procrastination and Low Time Management on Student Self Efficacy (at MA Soebono Mantofani). PINISI Discretion Review, 2(1), 85-92. 